\title{
The influence of zinc deficiency on chronic pain in Sprague Dawley rats
}

\author{
Hari Bagianto \\ Medical Faculty Brawijaya University, Malang, Indonesia.
}

\begin{abstract}
Abstrak
Tujuan Defisiensi Zinc (Zn) merupakan masalah pada sebagian besar negara-negara berkembang termasuk Indonesia, khususnya di kepulauan Nusa Tenggara Timur (NTT). Zn memegang peranan penting dalam proses nyeri melalui proses modulasi pada reseptor $N$-methyl-D-aspartate (NMDA), yang juga melibatkan neuronal nitric oxide synthase (nNOS) sebagai parameter nyeri. Penelitian ini dilakukan untuk mengetahui peranan Zn terhadap respons nyeri dan terhadap modulasi nyeri pada tingkat medulla spinalis pada tikus.
\end{abstract}

Metode Dua puluh tikus Sparague Dawley (SD) dibagi menjadi dua grup, yaitu grup normal dan grup defisien (grup defisien diberi makanan diet IRI-OB). Lebih lanjut tiap grup dibagi lagi menjadi dua subgrup, yaitu subgrup nyeri akut (stimulasi nyeri sesaat), dan subgrup nyeri kronik (stimulasi nyeri kontinu). Subgrup nyeri kronik dilakukan dengan cara operasi CCI Bennet pada tikus dalam grup ini. Ambang nyeri pada grup defisien dan grup normal diukur secara klinis menggunakan tes plantar modifikasi Ugo Basille (thermal transient noxious stimuli). Pengukuran nyeri kronik dilakukan dengan mengukur kadar nNOS secara imuno-histo-kimia.

Hasil Kelompok defisien menunjukkan penurunan ambang nyeri yang tidak signifikan $(P=0,251)$. Akan tetapi, terdapat peningkatan signifikan nNOS $(P=0,027)$, terutama pada grup defisiensi dengan stimulasi nyeri kontinu.

Kesimpulan Hasil penelitian ini menunjukkan bahwa defisiensi Zn meningkatkan respons nyeri, khususnya pada nyeri kronis. (Med J Indones 2010; 19:88-95)

\begin{abstract}
Aim Zinc (Zn) deficiency remains a problem in most developing countries, including Indonesia, especially in the East Nusa Tenggara (NTT) Islands. Zinc plays a major role in pain through the modulation process by the N-methyl-Daspartate (NMDA) receptors, which also includes neuronal nitric oxide synthase (nNOS) as a pain parameter. The purpose of this study is to reveal the effects of $\mathrm{Zn}$ towards pain response and modulation stage at the spinal cord level in rats.

Methods Twenty Sprague Dawley (SD) rats were divided into two groups, a deficient group and a normal group. The deficient group was fed on an IRI-OB diet. Every group was further divided into two more groups, the acute pain group (transient noxious stimuli), and the chronic pain group (continuous noxious stimuli). The rats in chronic pain group were subjected to CCI Bennet operation. The pain thresholds in the deficient group and normal group were measured clinically using a modified Ugo Basille plantar test (thermal transient noxious stimuli). Measurement of chronic pain level was carried out by measuring the nNOS level by immunohistochemistry.

Results Deficient group showed an insignificant decrease in pain threshold $(P=0.251)$. However, there is a significant increase in $\operatorname{nNOS}(P=0.027)$ especially in the deficient group with continuous noxious stimulation.

Conclusions These results suggest that $\mathrm{Zn}$ deficiency increases pain response, especially in chronic pain. (Med $\boldsymbol{J}$ Indones 2010; 19:88-95)
\end{abstract}

Key words: continuous noxious stimuli, nNOS, plantar test, transient noxious stimuli

In developing country including Indonesia, especially Nusa Tenggara Timur (NTT) islands, micronutrient deficiency including zinc $(\mathrm{Zn})$ deficiency is still a crucial problem. Another study in Central Java also showed that the prevalence of serum zinc deficiency was 70-90\%. A small-scale study (1997-1999) in West Java, Central Java and Lombok showed that the prevalence of zinc deficiency among infants was from 6 to $39 \% .^{1,2}$ Zinc is an essential element for growing and developing process, because it is considered an essential component for over 200 kinds of metaloenzymes with various syntethic and degradatation activities of almost all metabolites (carbohydrate, protein, fat, nucleic acid). Moreover, zinc metaloenzyme monitors replication, transcription, and translation of genetic elements. Based on that, it is considered that $\mathrm{Zn}$ deficiency will bring a large impact on numerous body systems. Zinc plays a major role on pain mechanism through modulation process by the N-methyl-D-aspartate (NMDA) receptors, which includes the neuronal nitric oxide synthase (nNOS) as the parameter of pain. ${ }^{3}$ 
The process of nociceptive pain consists of 4 stages, which are transduction, transmission, modulation and perception. Studies on the transduction and transmission stages have been done a lot, and most of them are established. The perception level is the most complex level, where many factors are involved. Therefore this study was focused on the modulation stage at the spinal cord level. Pain modulation is determined by the balance of inhibitory and excitatory receptors.

The NMDA receptors play an important role on the chronic pain modulation process. ${ }^{4}$ Zinc slows down the NMDA receptor activities through inhibition of glycine receptor binding. ${ }^{5}$ The decrease of Zinc atom however will make glycine-NMDA receptor binding easier and increase NMDA receptors excitability. This will increase the calcium ion intake through ion channel related NMDA receptors, which will later activate nNOS and ends up with the increase of Nitric-Oxide (NO) in the cytosol. Nitric-Oxide as a gas will immediately spread to presynaptic neuron cells and stimulates glutamate production, which will increase the stimulus on NMDA receptor and causes hyperalgesia. Eventhough at transient noxious stimulus NMDA receptors can not open the ion channel, NMDA receptor can still produce cytosol $\mathrm{Ca}^{2+}$ ions and $\mathrm{NO}$ through this way.

Based on the studies above, $\mathrm{Zn}$ atoms can reduce the pain response (inhibitory) through inhibition at glycine as NMDA receptor's coagonist, but also increase pain response (excitatory) through protein kinase $\mathrm{C}-\alpha$ (PKC- $\alpha$ ) activation, which will phosphorilate NMDA receptors. The fact is, on normal $\mathrm{Zn}$ level, chronic pain can still occur. It means that the NMDA receptors can still be active even at normal $\mathrm{Zn}$ condition.

The purpose of this study was to reveal the effects of $\mathrm{Zn}$ towards pain response and modulation stage at the spinal cord level. We evaluated the effects of $\mathrm{Zn}$ toward pain response by measuring experimental animal responses to transient and continous noxious stimuli. Modulation stage at the spinal cord level was evaluated by measuring nNOS level in transient and continous noxious stimuli.

\section{METHODS}

Twenty male Sprague Dawley (SD) rats weighing 350$400 \mathrm{~g}$ were divided into deficient and normal groups. The deficient group was fed on IRI-OB diet for 2 months. The IRI-OB diet is a diet devoid of $\mathrm{Zn}$, according to van Wouwe, J.P. et al 1986. ${ }^{11}$ This treatment creates chronic $\mathrm{Zn}$ deficiency.

Furthermore, each group was divided into 2 more groups, chronic pain group (continuous noxious stimuli) and acute pain group (transient noxious stimuli). The chronic pain group was engineered by chronic constriction injury $(\mathrm{CCI})$ that was done by Bennet operation, in which the rats were anesthetized using Nembutal (50mg/kg bodyweight), and the common sciatic nerve of the left hind paw was exposed at the level of the middle of the thigh by blunt dissection through the biceps femoris. Proximal to the sciatic trifurcation, approximately $7 \mathrm{~mm}$ of nerve was freed, and 4 loose ligatures of 4-0 chromic gut were placed around the sciatic nerve for 3-7 days. ${ }^{13}$

$\mathrm{Zn}$ status was checked at tibial bone, because it has the most stable level than any other organs (hair, plasma, muscle etc.). Tibial bone was measured in weight, and reduced to ashes by $800^{\circ} \mathrm{C}$ flaming for 2 hours. Ashes of the bone were diluted in water and the level of $\mathrm{Zn}$ were evaluated with Shimatsu AA 6200 atomic absorption spectrophotometry (AAS) with ELISA technique. ${ }^{11}$

Pain examination was done clinically on deficient and normal groups with plantar test equipment (modified Ugo Basille). Plantar test is a transient noxious thermal stimulation; therefore acute pain threshold is being measured. In the chronic pain group, the rats got continuous noxious stimulation. Therefore, pain measurement using plantar test equipment is no longer valid. Pain measurements on chronic group (continuous noxious stimulation) and acute group (transient noxious stimulation) were done by measuring $\mathrm{nNOS}$ expression using immunohistochemistry method.

Immunohistochemistry method to reveal the nNOS expression was started with the preparation of slides of rats spinal cords. Principally the slides were blocked with $\mathrm{H}_{2} \mathrm{O}_{2}$ and NGS (normal goat serum); washed with phosphate buffered saline (PBS) $p \mathrm{H}$ 7.4, incubated in primary (anti-rat nNOS) antibody and then imunoperoxidase linked secondary antibody and finally visualized using DAB substrate. The end results were evaluated microscopically. ${ }^{12}$

Statistical analysis was performed on the raw data using two-way analysis of variance (ANOVA) for repeated measures, followed by post-hoc Tukey's protected t-test when significant differences between the normal and defficient groups were seen. Values of $P<0.05$ were taken as statistically significant. 


\section{RESULTS}

\section{Mean body weight for normal and deficient group}

Levene equality test showed no significant difference between the two groups $(P=0.164)$. Further, the weight of rats in normal compared to the deficient group showed no significant difference $(P=0.761)$. These results proved the homogenity of the two groups. (Table 1)

Table 1. Mean body weight of normal and deficient group

\begin{tabular}{lccc}
\hline Group & N & $\begin{array}{c}\text { Body weight (gram) } \\
\text { Mean } \pm \text { SD }\end{array}$ & Difference \\
\hline Normal & 10 & $423.8 \pm 32.0$ & $P=0.761$ \\
Deficient & 10 & $427.4 \pm 19.9$ & \\
\hline
\end{tabular}

\section{Mean $\mathrm{Zn}$ level in normal and deficient group}

Levene equality test showed a significant difference between the two groups $(P=0.007)$. Further, the $Z n$ level for rats fed on normal $\mathrm{Zn}$ diet compared to the $\mathrm{Zn}$ restriction diet showed a significant difference $(P=0.001)$. The $\mathrm{Zn}$ level in normal groups were higher. This results proved that the low $\mathrm{Zn}$ diet treatment was able to create a Zn deficiency condition (Table 2).

Table 2. Mean $\mathrm{Zn}$ level for normal and deficient group

\begin{tabular}{lcll}
\hline Group & N & $\begin{array}{c}\text { Zn level }(\boldsymbol{\mu g} / \mathbf{L}) \\
\text { Mean } \pm \text { SD }\end{array}$ & Difference \\
\hline Normal & 10 & $2679.2 \pm 254.1$ & $P=0.001$ \\
Deficient & 10 & $516.1 \pm 40.7$ & \\
\hline
\end{tabular}

\section{Mean plantar test for normal and deficient group}

Even though Levene equality test showed a significant difference between the two groups $(P=0.003)$, the plantar test on the deficient group was not significantly different from the normal group $(P=0.251)$. The deficient group showed less value than normal group even though the difference was not significant. This result proved that the low $\mathrm{Zn}$ diet was not able to decrease the threshold of transient noxious stimulation significantly (Table 3 ).

Table 3. Mean plantar test for normal and deficient group

\begin{tabular}{lccl}
\hline Group & N & $\begin{array}{c}\text { Plantar test (seconds) } \\
\text { Mean } \pm \text { SD }\end{array}$ & Difference \\
\hline Normal & 10 & $32.2 \pm 2.2$ & $P=0.251$ \\
Deficient & 10 & $29.1 \pm 7.9$ & \\
\hline
\end{tabular}

\section{F test for nNOS of all groups}

F test (ANOVA) for nNOS in the four groups (continuous noxious stimuli on normal group, continuous noxious stimuli on deficient group, transient noxious stimuli on normal group, and transient noxious stimuli on normal group) showed a significant difference $(P=0.001)$. The nNOS overall value was higher on the deficient groups and the continuous noxious stimuli. The highest value of nNOS was found in continuous noxious stimuli on deficient group. The lowest value of nNOS was found in transient noxious stimuli on normal group (Table 4).

Table 4. F test for nNOS of all groups

\begin{tabular}{llcccc}
\hline \multirow{2}{*}{ Group } & \multicolumn{5}{c}{ nNOS (cell/visual field, mean \pm SD) } \\
\cline { 2 - 6 } & N & Transient Noxious & N & Continuous Noxious & Difference \\
\hline Normal & $\mathbf{5}$ & $4.4 \pm 1.5$ & $\mathbf{5}$ & $11,6 \pm 1,5$ & \multirow{2}{*}{$P=0.001$} \\
Deficient & $\mathbf{5}$ & $9.0 \pm 3.4$ & $\mathbf{5}$ & $16,8 \pm 3,3$ & \\
\hline
\end{tabular}

The Tukey test showed that the nNOS value in normal group with acute pain compared to deficient group with acute pain showed no significant difference, the same as the result of chronic compared to acute pain in normal group. The deficient group with chronic pain showed the highest nNOS value that was different significantly compared to other groups (Table 5).

Table 5. Tukey test among dependent variable: nNOS

\begin{tabular}{lcc}
\hline Groups & Mean \pm SD & N \\
\hline Continuous noxious stimuli on normal group & $11.6 \pm 1.5$ & 5 \\
Transient noxious stimuli on normal group & $4.4 \pm 1.5$ & 5 \\
Continuous noxious stimuli on deficient group & $16.8 \pm 3.3$ & 5 \\
Transient noxious stimuli on deficient group & $9.0 \pm 3.4$ & 5 \\
\hline
\end{tabular}

In general, this study showed that in the deficient groups, there was an insignificant decrease in plantar test result from $32.2 \pm 2.2$ seconds to $29.1 \pm 7.9$ seconds $(P=0.251)$. This fact means that $\mathrm{Zn}$ deficiency doesn't affect acute pain, because plantar test measure the pain threshold. However, a significant increase occured in nNOS $(P=0.001)$ especially in the normal and deficient group with chronic pain, which was $11.6 \pm 1.5 \mathrm{cell} / \mathrm{VF}$ to $16.8 \pm 3.3 \mathrm{cell} / \mathrm{VF}(P=0.027)$. On the other hand, acute pain caused insignificant increase in nNOS, from $4.4 \pm 1.5 \mathrm{cell} / \mathrm{VF}$ to $9.0 \pm 3.4 \mathrm{cell} / \mathrm{VF}(P=0.055)$. On the normal group, chronic compared to acute pain still produced a significant increase in nNOS from $4.4 \pm 1.5$ cell $/ \mathrm{VF}$ to $11.6 \pm 1.5 \mathrm{cell} / \mathrm{VF}(P=0.002)$. 


\section{DISCUSSION}

The NMDA receptor plays an important role in chronic pain. ${ }^{4}$ Zinc inhibits the NMDA receptor through the blockade of this receptor binding with glycine. ${ }^{5}$ The NMDA receptor is a ligand and voltage dependent receptor. There are four mechanisms to activate NMDA receptor, ${ }^{6}$ i.e. glutamate binding as ligand, glycine binding as co-agonist, the release of $\mathrm{Mg}+$ blockade by strong enough membrane depolarization that is caused by strong and repetitive stimuli, and PKC $\alpha$ phosphorilation

The presynaptic neurons release three kinds of neurotransmitters in the transduction of noxious stimuli, i.e. substance P (SP), glutamate and glycine. The main receptors in post synaptic neurons are SP receptor neurokinin receptor (NK-R), alfa-amino 3-hydroxy 5-methyl 4-isoxazolepropionic acid receptor (AMPA-R), NMDA receptor (NMDA-R), and metabotropic glutamate receptor (mGlu-R). The last three receptors are ionotropics. ${ }^{7}$

In normal $\mathrm{Zn}$ level, transient noxious stimuli impulse that flows through AMPA-R and Neurokinin-1 (NKR-1) depolarizes, but is not strong enough to cast aside the $\mathrm{Mg}^{2+}$ blockade by the ionic valve that is bound to NMDA-R, so the NMDA-R remains inactive (Figure 1).

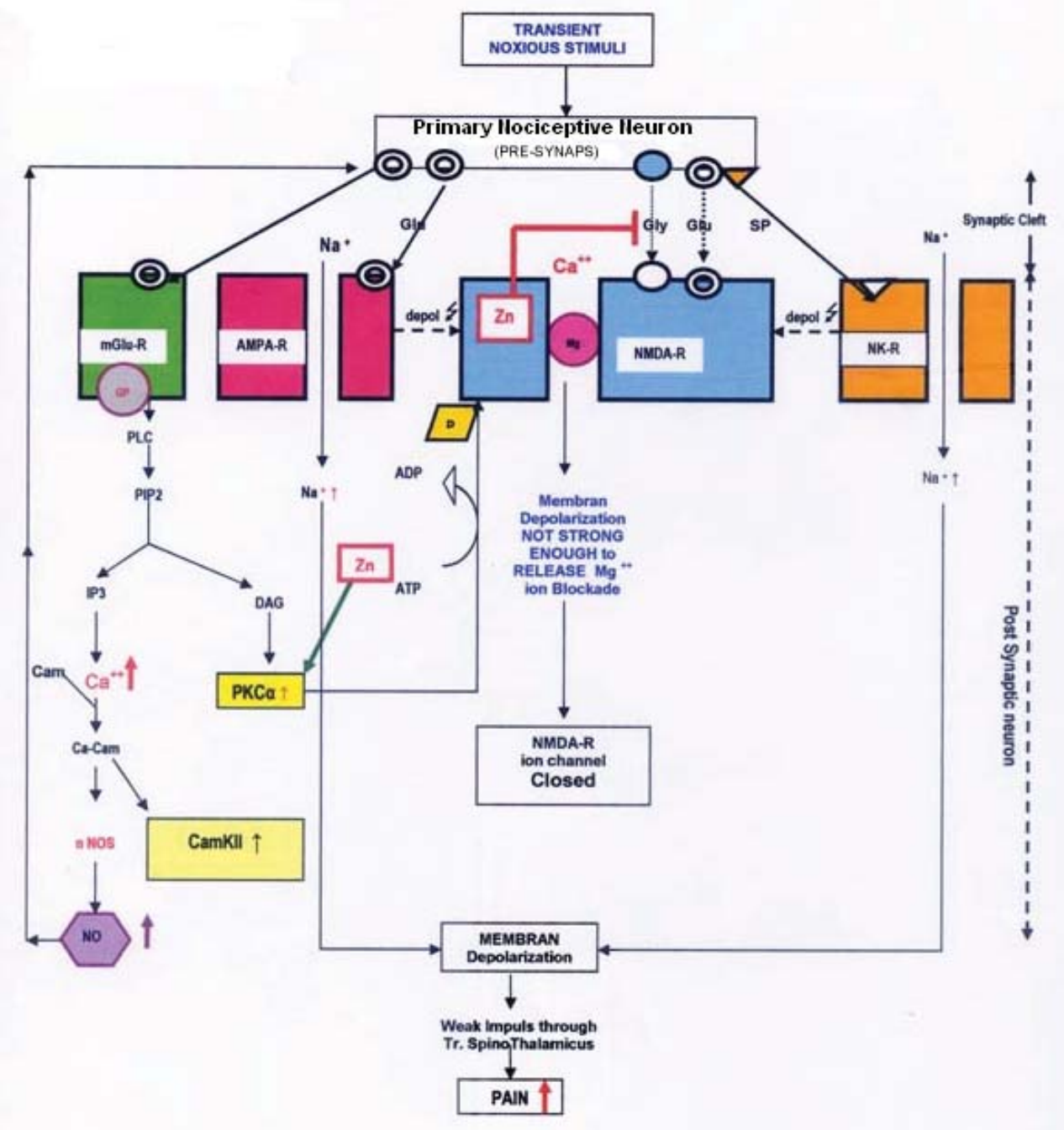

Figure 1. Scheme of transient noxious stimuli at normal Zn level 


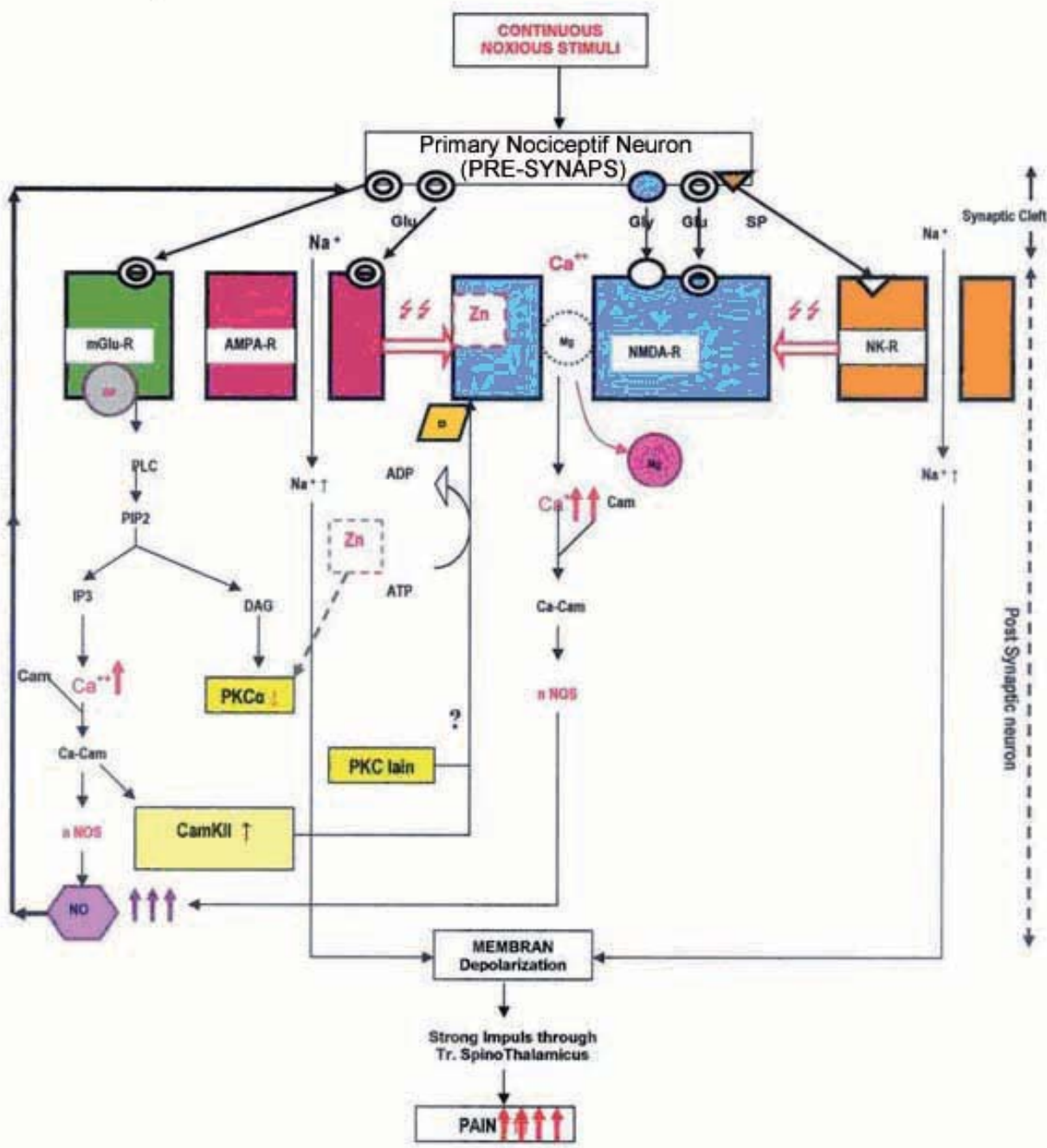

Figure 2. Scheme of continuous noxious stimuli at normal Zn level

Transient noxious stimuli on mGlu-R will turn PIP2 into inositol triphosphate (IP3) and diacyl glycerol (DAG) that would activate the PKC- $\alpha$ and produce nitric oxide (NO) out of nNOS. ${ }^{8}$ Protein kinase $\mathrm{C}-\alpha$ will activate NMDA-R through phosphorilation. To activate one molecule of cytosol PKC- $\alpha, 4 \mathrm{Zn}$ atoms are required. ${ }^{9}$ Therefore, $\mathrm{PKC}-\alpha$ activities are assumed to decrease at $\mathrm{Zn}$ deficiency, and so are NMDA-R activities. Inositol triphosphate that is produced by mGlu-R will stimulate $\mathrm{Ca}^{2+}$ ions out of endoplasmic reticulum, which is an intracellular $\mathrm{Ca}$ ion deposit. This $\mathrm{Ca}^{2+}$ ion binds to calmudolin and will activate nNOS, which will increase cytosol NO. Nitric-oxide as a gas will immediately spread to presynaptic neuron cell and stimulates glutamate production that will increase the stimulus on NMDA-R and creates hyperalgesia.
Due to strong or continuous noxious stimuli, the impulse of noxious stimuli in the AMPA-R becomes strong enough to release the $\mathrm{Mg}^{2+}$ ion blockade in the $\mathrm{Ca}^{2+}$ valve that is bound to NMDA-R, allowing the entrance of sodium and calcium ion and the exit of potassium ion through the ionic valve (Figure 2).

The NMDA-R has to bind glycine to be able to receive the impulse of glutamate neurotransmitter, while the binding was inhibited by Zn. Thus the NMDA-R does not work optimally, and could not produce sufficient NO that is required to cause chronic pain.

In transient noxious stimuli(Figure 3), Zn deficiency will weaken the inhibition of glycine binding that facilitate the NMDA-R to bind with glutamate, while AMPA-R and NKR-R depolarize, but is not strong enough to 
cast aside the $\mathrm{Mg} 2+$ blockade in the ionic valve that is bound to NMDA-R, so the NMDA-R remains inactive, and the cytosol $\mathrm{Ca}^{2+}$ does not increase, thus does not activate nNOS to produce NO and chronic pain.

The activation of mGlu-R will activate PKC through PIP2 pathway where DAG activates PKC- $\alpha$. The PKC- $\alpha$ will activate NMDA-R through phosphorilation. To activate one molecule of cytosol PKC- $\alpha, 4 \mathrm{Zn}$ atoms are required. ${ }^{9}$ Therefore, PKC- $\alpha$ activities are assumed to decrease at Zn deficiency state, and so are NMDA-R activities, and results in reduced pain.
Nevertheless, there's a possibility that NMDA-R is phosphorilized by other protein kinase, such as Cacalmodulin dependent protein kinase II (CaMKII) that is produced by mGlu-R. Phosphorilation of AMPA-R by CaMKII and PKC- $\alpha$ can be seen either in vitro or in vivo. ${ }^{10}$ If the same condition happens in NMDA-R, $\mathrm{Zn}$ deficiency will not affect phosphorilation of NMDA-R (Figure 4). Figure 4 explains that $\mathrm{Zn}$ deficiency might increase the activity of NMDA-R even though there's a decrease in the activity of PKC- $\alpha$ enzyme.

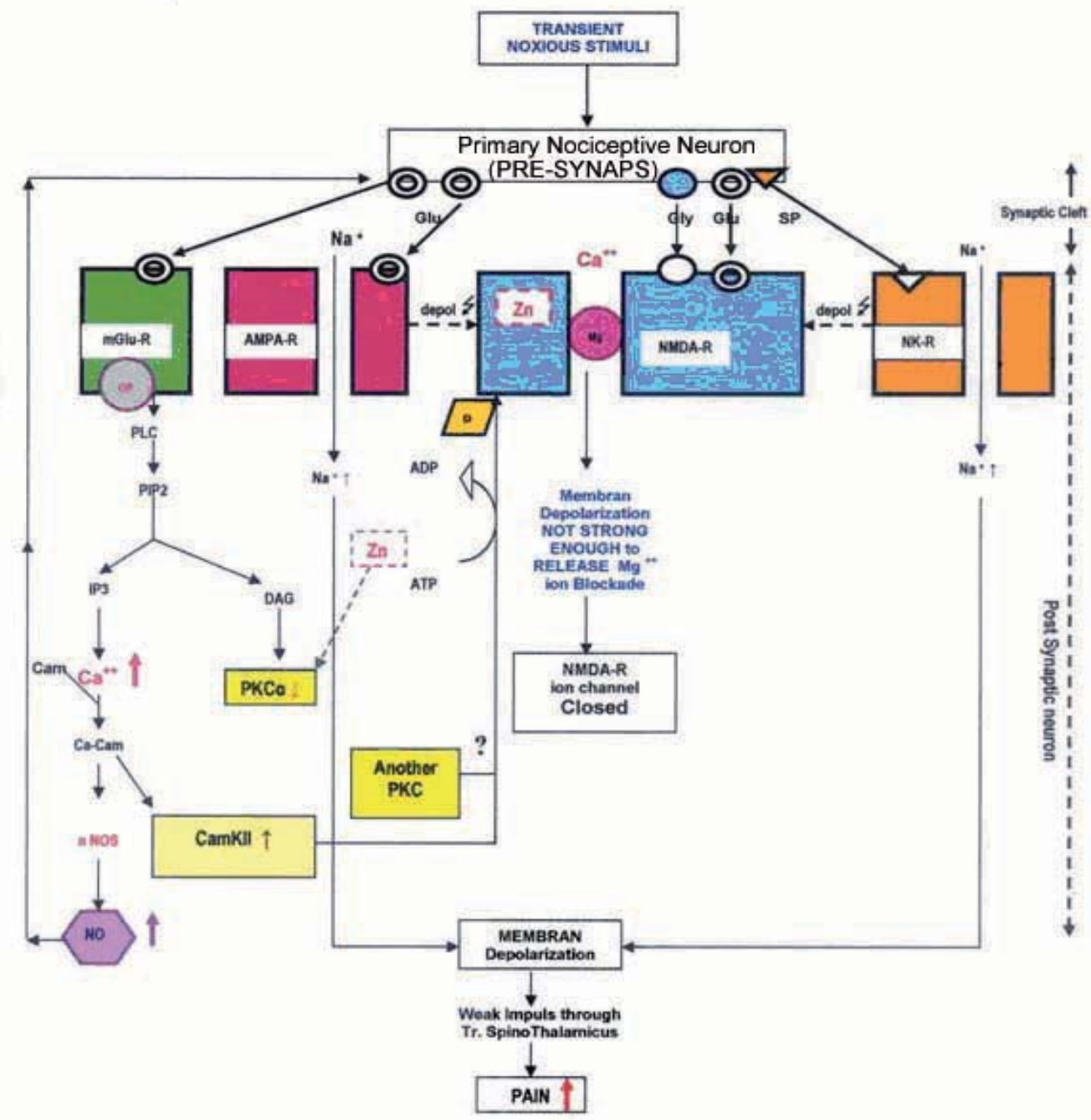

Figure 3. Scheme of transient noxious stimuli at Zn deficiency level 


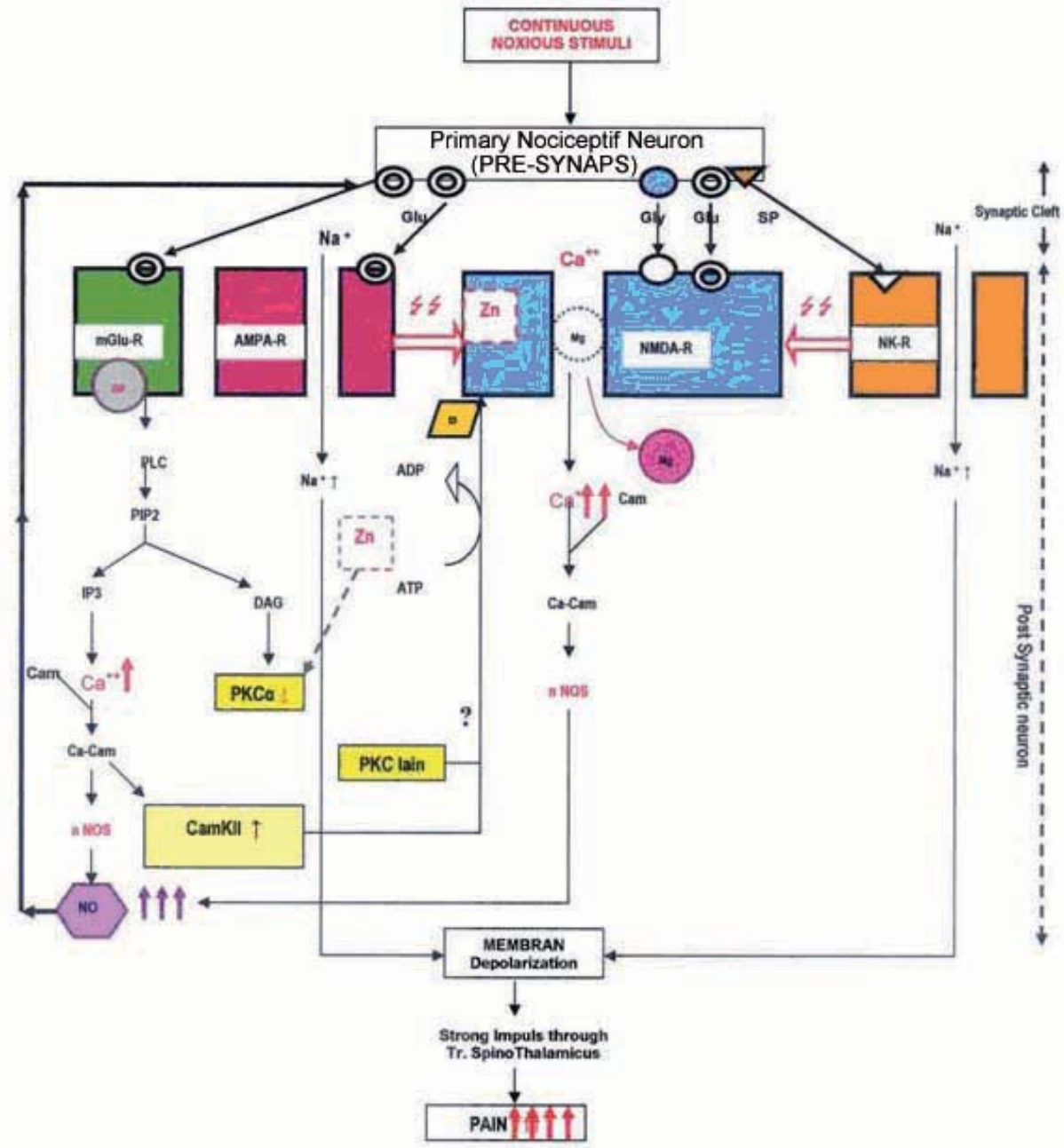

Figure 4. Scheme of continuous noxious stimuli at Zn deficiency level

Our result proved that the low $\mathrm{Zn}$ diet treatment was not able to decrease the threshold of transient noxious stimulation. This result is similar to the clinical phenomenon in NTT in which there were no differences in labiopalatoschizis reconstruction postoperative pain between NTT island population group (which is assumed as a $\mathrm{Zn}$ deficiency group) and Java island population group (which is assumed as the group with normal $\mathrm{Zn}$ level). In chronic stimuli group, the plantar test was not performed, because rats plantars in this group suffered from drop foot.

Our result showed that there was no significant difference in bodyweight between $\mathrm{Zn}$ deficient and normal group. This fact can be caused by adaptation process in diet, which was given for 7 weeks. Zn deficiency will increase nNOS, while continous noxious stimuli will increase
nNOS in higher level. We found that the highest nNOS was produced by continous noxious stimuli in $\mathrm{Zn}$ deficient group $(P=0.001)$. Tukey test showed that there was a significant higher nNOS value in chronic pain and $\mathrm{Zn}$ deficient group. The reason for this result is that in $\mathrm{Zn}$ deficient group, glycine easily binds to NMDA-R, and facilitate glutamate as the ligand to bind to NMDA-R.

Transient noxious stimuli can not initiate NMDA-R depolarization. Therefore, calcium ion chanels that is bound to NMDA-R is opened and calcium does not enter and nNOS is not increased. In transient noxious stimuli, nNOS can be formed by mGlu-R, which is a receptor that is bound to G protein. The PIP2 is turned into IP3, and DAG activates the PKC- $\alpha$ and produces $\mathrm{NO}$ out of nNOS. Protein kinase $\mathrm{C}-\alpha$ activates 
NMDA-R through phosphorilation. The IP3 will move closely to endoplasmic reticulum as intracellular $\mathrm{Ca}$ ion deposit. Endoplasmic reticulum will release $\mathrm{Ca}$ ion to cytosol to bind calmodulin and initiate $\mathrm{NO}$ formation by nNOS, or produce CaMKII that is influenced by $\mathrm{Zn}$ ion. We suggested that this kinase replaced PKC- $\alpha$ to phosphorilate NMDA-R. Continous noxious stimuli will give adequate stimuli to initiate strong depolarization to open calcium channel. Therefore, calcium ion will enter cytosol, binds calmodulin and activate more nNOS to produce NO.

In general, our result showed that on the $\mathrm{Zn}$ deficient groups, there was an insignificant decrease in plantar test. The fact means that Zn deficiency doesn't affect acute pain because plantar test measures the pain threshold. However, a significant increase occur in $\mathrm{nNOS}(P=0.001)$ especially in the deficient group with chronic pain. On the deficient group with acute pain an unsignificant increase of nNOS occured. On the normal group, continuous noxious stimuli compared with transient noxious stimuli still produce a significant increase of nNOS. Calcium ion plays a role in $\mathrm{NO}$ and CaMKII formation through mGlu-R that activates PKC enzyme.

In conclusion, $\mathrm{Zn}$ deficiency increased pain response, especially in chronic pain. On rats with normal Zn, activation of the NMDA receptor might still occur, which was due to phosphorilation by PKC other than the Zn-dependent PKC- $\alpha$.

\section{REFERENCES}

1. Atmarita. Nutrition problems in Indonesia. Integrated International seminar and workshop on lifestyle-related diseases. 2005. March 19 - 20; Yogyakarta, Indonesia. Yogyakarta: Directorate of Community Nutrition, The Ministry of Health of Indonesia; 2005.

2. Prasad AS. Zn deficiency. BMJ. 2003;326:409-10

3. Mungiu QC, Ionescu DG, Jaba IM. Zn and nociception: a pharmacological approach. Rev Med Nat lasi. 2002; 106(1):10-3.

4. Petrenko AB, Yamakura T, Baba H, Shimoji K. Pain medicine. The role of N-Methyl-D-Aspartate (NMDA) receptors in pain: a review. Anesth Analg. 2003; 97:1108-16.

5. Suwa H, Amant LS, Triller A, Drapeau L, Pasca L. Highaffinity Zinc potentiation of inhibitory postsynaptic glycinergic currents in the Zebrafish hindbrain. J Neuro Physiol. 2001;85 (2): 912-25.

6. Mello RD, Dickenson AH. Spinal cord mechanisms of pain. Br J Anesth. 2008; 101(1):8-16.

7. Conn PJ, Niswender CM. Review: Metabotropic glutamate receptors: physiology, pharmacology, and disease. Annu Rev Pharmacol Toxico. 2010; 50:295-322.

8. Newton, Alexandra C. Protein kinase C: structural and spatial regulation by phosphorylation, cofactors, and macromolecular interactions in protein phosphorylation. Chem Rev. 2001; 101, 2353-64.

9. AF Quest, Bloomenthal J, Bardes ES, Bell RM. The regulatory domain of protein kinase $\mathrm{C}$ coordinates four atoms of Zinc. J Biol Chem. 1992; 267(14). 101193-7

10. Revest $\mathrm{P}$, Longstaff $\mathrm{A}$. Metabotropic receptors and signal transduction mechanism. In: Clarke AJ. editor Molecular Neuroscience. Oxford; Garland Science: 1998. pp.72-86

11. Van Wouwe JP, Veldhuizen M, Goiej JJ, Hamer CJ. Laboratory assesment of early dietary, subclinical zinc deficiency: a model study on weaning rats. Pediatr Res. 1991:391-5.

12. Soini Y, Paakko P, Lehto VP. Histopathological Evaluation of Apoptosis in Cancer. AmJ Pathol. 1998: 153: 1041-53.

13. Kris V, Hugo A, Roland DC, Cathy DD, Theo FM. A chronicconstriction injury of the Sciatic nerve reduces bilaterally the responsiveness to formalin in rats: A behavioral and hormonal evaluation. Anesth Analg. 2003; 97:520-5. 